\title{
MENGGALI NILAI-NILAI KARAKTER DALAM PERMAINAN MAGOAK-GOAKAN DESA PANJI KECAMATAN SUKASADA SEBAGAI SUMBER BAHAN PENGAYAAN PEMBELAJARAN IPS DI SMP NEGERI 4 SINGARAJA
}

\author{
I Nyoman Tri Esaputra ${ }^{1}$, I Made Pageh ${ }^{2}$, Tuty Maryati ${ }^{3}$ \\ Program Studi Pendidikan IPS Pascasarjana Universitas Pendidikan Ganesha Singaraja, Indonesia \\ e-mail: inyomantriesaputra@gmail.com ${ }^{1}$, imadepageh@undiksha.ac.id ${ }^{2}$, tutymaryati@undiksha.ac.id ${ }^{3}$
}

\begin{abstract}
Abstrak
Penelitian ini bertujuan; Untuk mengetahui latar belakang sejarah permainan magoak-goakan, Untuk mengetahui nilai-nilai karakter yang terkandung dalam permainan magoak-goakan, Untuk mengetahui bentuk pengintegrasian permainan magoak-goakan ke dalam pembelajaran IPS. Penelitian ini menggunakan pendekatan kualitatif. Peneliti menentukan tiga lokasi penelitian, yaitu, Pura Pajenengan, Banjar Dauh Pura Desa Panji, dan SMP Negeri 4 Singaraja. Data yang digunakan dalam penelitian ini dikumpulkan teknik pengumpulan data yakni, wawancara, observasi dan studi dokumen. Hasil penelitian ini menunjukan bahwa; (1) permainan magoak-goakan merupakan strategi Gusti Ngurah Panji Sakti untuk mempersatukan suara rakyat dalam usahanya berperang melawan kerajaan Blambangan; (2) Nilai-nilai karakter yang terkandung dalam permainan magoak-goakan yakni: nilai disiplin, nilai kerjasama, nilai religius, nilai toleransi, nilai kerja keras, dan nilai komunikatif; (3) Adapun strategi pengintegrasian nilai-nilai karakter dalam permainan magoak-goakan ke dalam pembelajaran IPS adalah dengan meninjau silabus, menentukan KD yang relevan, memilih topik pada buku ajar yang relevan, menyusun RPP mengaplikasikan permainan magoak-goakan sebagai sumber belajar.
\end{abstract}

Kata Kunci:nilai karakter, permainan magoak-goakan, pendidikan IPS

\section{Abstract}

This study aimed at finding out: the historical background of the game Magoak-goakan, character values contained in the game Magoak-goakan, the form of the integrating of the game Magoak-goakan into the form of teaching of Social Studies. The study used the research design of qualitative approach or method. The data used in this study were collected by applying various techniques of data collection: interview, observation and document study. The results showed that (1) the game Magoak-goakan was a strategy used by Ki Barak Panji Sakti to unify the voice of the people in the war against Blambangan Kongdom; (2) The character values contained in the game Magoak-goakan are discipline, coorperation, religious value, tolerance, hard work, and communicativeness (3) The strategy to integrate character values in the game Magoak-goakan into the teaching of Social Studies is by (1) reviewing the syllabus, (2) determining relevant basic competences, (3) choosing topics in the relevant textbooks, (4) writing a lesson plan that reflects the application of the game Magoak-goakan as a learning resource.

Keywords:Character values, the Game Magoak-goakan, Social Studies Education 


\section{Pendahuluan}

Indonesia merupakan sebuah negara yang sangat unik, terlebih jika dikaji dari struktur masyarakat dan budayanya. Struktur masyarakat Indonesia ditandai oleh dua ciri. Secara horizontal, ia ditandai oleh kenyataan adanya kesatuan-kesatuan sosial berdasarkan perbedaan-perbedaan suku bangsa, perbedaan-perbedaan agama, adat serta perbedaanperbedaan kedaerahan. Secara vertikal, struktur masyarakat Indonesia ditandai oleh adanya perbedaan-perbedaan vertikal antara lapisan atas dan lapisan bawah yang cukup tajam (Kumbara, 2012).

Bangsa Indonesia yang hidup menyebar pada ribuan pulau-pulau yang terangkai dalam satu gugusan memiliki corak identitas, pola tingkah laku, unsur-unsur budaya yang beragam berdasarkan daerah kebudayaan tertentu (Sihabuddin, 2006). Keberagaman budaya yang ada di Indonesia terjadi karena manusia mampu mengembangkan kesenian, ilmu dan teknologi yang memungkinkan memiliki kehidupan yang selalu meningkat ke arah yang lebih baik. Manusia dengan kemampuan akal pikirannya selalu ingin mengetahui, ingin mencari, mencoba, menyelidiki, menemukan hal-hal baru, berhubungan dengan kebutuhannya. Dengan panca inderanya, manusia juga mampu mengembangkan rasa keindahan, kehalusan budi, melahirkan karya-karya seni yang indah. Tegasnya, manusia adalah makhluk kebudayaan (Sihabuddin, 2006)

Kebudayaan menurut Koentjaraningrat (1990) adalah keseluruhan sistem gagasan, tindakan dan hasil karya manusia dalam rangka kehidupan masyarakat yang dijadikan milik diri manusia dengan belajar. Sayangnya, kekayaan budaya yang dimiliki suku-suku bangsa di hamparan khatulistiwa ini sebagian besar masih dalam bentuk yang tidak tertulis. Tidak semua kekayaan itu dapat kita jumpai dalam dokumen yang tertulis. Kekayaan itu misalnya kita dapati dalam bentuk adat-istiadat, cerita rakyat, dan lainnya yang sebagian kita dapat melalui deskripsi ungkapan lisan (Sihabuddin, 2006). Kebudayaan-kebudayaan tersebut disebut dengan istilah folklor.

Foklor merupakan sebagian kebudayaan suatu kolektif yang tersebar dan diwariskan secara turun-menurun, di antara kolektif macam apa saja, secara tradisional dalam versi yang berbeda, baik dalam bentuk lisan maupun disertai dengan gerak isyarat atau alat pembantu pengingat (mnemonic device) (Danandjaja, 2002:2). Menurut Jan Harold Brunvard (dalam Danandjaja, 2002:21), ahli folklor dari Amerika Serikat, folklor dapat digolongkan ke dalam tiga kelompok besar berdasarkan tipenya, yakni: Foklor lisan, foklor sebagian lisan, foklor bukan lisan.

Kebudayaan-kebudayaan yang kita dapat melalui foklor sebagian lisan salah satunya adalah permainan rakyat. Menurut James Danandjaja (2002) setiap bangsa di dunia ini umumnya mempunyai permainan rakyat. Kegiatan ini juga termasuk folklor karena diperolehnya melalui warisan sebagian lisan. Hal ini terutama berlaku pada permainan kanak-kanak, karena permainan ini disebarkan hampir murni melalui tradisi lisan dan banyak di antaranya disebarluaskan tanpa bantuan orang dewasa seperti orangtua mereka atau guru di sekolah mereka.

Berdasarkan perbedaan sifat permainan, maka permainan rakyat (folk games) dapat dibagi menjadi dua golongan besar, yaitu permainan untuk bermain (play) dan permainan untuk bertanding (game). Perbedaan permainan bermain dan permainan bertanding adalah bahwa permainan bermain lebih bersifat untuk mengisi waktu senggang atau rekreasi, sedangkan permainan bertanding lebih bersifat perlombaan (competitive) (Danandjaja, 2002)

Ada berbagai macam permainan tradisional yang terdapat di Indonesia, seperti permainan Gobag Sodor dari Yogyakarta, Ngadu Muncang dari Jawa Barat (Sunda), Maqgalenceng dari Sulawesi, Beteweh dari Kalimantan, Gala Hembek dari Sumatra, Magoak-goakan dari Bali dan permainan-permainan tradisional lainnya. Tentunya permainan-permainan tradisional tersebut harus dijaga dan dilestarikan karena merupakan warisan budaya bangsa. 
Permainan Magoak-goakan adalah permainan yang berasal dari Bali khususnya Bali Utara. Permainan Magoak-goakan sudah ada pada abad ke-16 pada masa pemerintahan Gusti Ngurah Panji Sakti saat beliau menjadi Raja Buleleng. Permainan Magoak-goakan merupakan strategi Ki Barak Panji Sakti yang ingin menyatukan rakyat dan para prajuritnya untuk membantu penyerangan ke wilayah Blambangan. Seperti yang diungkapkan oleh I Wayan Sujana selaku Kepala Bidang Kesenian Dinas Kebudayaan Kabupaten Buleleng. Beliau mengatakan bahwa:

Sebenarnya permainan Magoak-goakan yang ada di Desa Panji itu adalah strategi I Gusti Ngurah Panji Sakti untuk mempersatukan rakyat dalam mendukung rencana beliau untuk dapat megegebug atau berperang melawan Blambangan (Sujana, 53 th, 7 November 2017)

Kini unsur-unsur permainan Magoak-goakan terdapat di Bali Utara khususnya di desa Panji, Kecamatan Sukasada Buleleng. Khusus untuk di desa Panji Kabupaten Buleleng (Bali Utara) permainan Magoak-goakan ini diadakan pada hari Ngembak Geni yaitu sehari setelah hari raya Nyepi (Windhu, 1986).

Menurut masyarakat Buleleng (Bali Utara) permainan Magoak-goakan benar-benar memiliki nilai heroik, karena berkat taktik inilah raja Ki Gusti Ngurah Panji Sakti dapat mengobarkan semangat juang yang spontan rakyatnya (Windhu, 1986). Daerah-daerah di luar Buleleng menganggap bahwa permainan ini merupakan permainan yang baik, karena di samping bernilai hiburan, olah raga, juga ada unsur seninya. Permainan Magoak-goakan benar-benar mendapat tempat tersendiri di hati masyarakat Bali. Bahkan sudah berkali-kali ditampilkan sebagai permainan dalam bentuk pertunjukan baik di TV maupun untuk dipertunjukan pada tamu-tamu negara. Karena melalui pertunjukan itu maka watak dan sifat heroik masyarakat Bali khusunya Buleleng dapat dipancarkan (Windhu, 1986).

Selain mengandung sifat heroik, permainan Magoak-goakan mengandung nilai-nilai karakter yang dapat membantu guru dalam melakukan penanaman nilai-nilai karakter kepada siswa dalam proses pembelajaran IPS. Mengingat selama ini siswa sering kali merasa bosan dengan pelajaran IPS di sekolah. Kebosanan itu timbul akibat kurang pahamnya siswa terhadap IPS, dan metode pembelajaran yang digunakan guru sering tidak berhasil menarik perhatian siswa. Bahkan guru sering kali tidak mempunyai acuan yang jelas, apalagi kreatifitas untuk menciptakan metode yang menarik untuk digunakan dalam mengajar. Kebosanan juga bisa timbul akibat materi pelajaran tidak sesuai dengan tingkat perkembangan dan konteks kehidupan siswa (Sihabuddin, 2006). Hal tersebut juga terlihat pada siswa SMP 4 Singaraja saat mengikuti pelajaran IPS. Menurut Guru IPS di SMP 4 Singaraja siswa akan tertarik belajar IPS jika materi dan metode saat mengajar mereka sukai. Oleh, karena itu perlu dicari alternatif materi pelajaran yang sesuai dengan sifat dan tujuan pendidikan IPS di sekolah.

Pada jenjang SMP khusunya mata pelajaran IPS guru dapat menanamkan nilai-nilai karakter kepada siswa dalam proses pembelajaran IPS. Pada kurikulum IPS tahun 2013 tercantum dalam Kompetensi Inti (KI): (1) siswa dituntut untuk menghargai dan menghayati ajaran agama yang dianutnya; (2) Menghargai dan menghayati prilaku jujur, disiplin, tanggung jawab, peduli, santun, percaya diri, dalam berinteraksi secara efektif dengan lingkungan sosial dan alam dalam jangkauan pergaulan dan keberadaannya. Akan tetapi belakangan ini banyak terjadi masalah sosial seperti seks bebas, narkoba, tawuran antarpelajar, dan masalah sosial lainnya yang bertentangan dengan nilai-nilai karakter bangsa.

Implementasi pendidikan karakter harus melibatkan metode, teknik dan materi yang membuat seseorang memiliki alasan atau keinginan untuk berbudi pekerti baik yang diawali dari pengetahuan terhadap nilai kebaikan sehingga akan terus mengembangkan sikap mencintai perbuatan baik dan akhirnya mau untuk melaksakan perbuatan baik tersebut (zuriah, 2007).

Pendidikan karakter mengemban misi untuk mengembangkan watak-watak dasar yang seharusnya dimiliki oleh peserta didik. Penghargaan (respect) dan tanggung jawab (responsibility) merupakan dua nilai moral pokok yang harus diajarkan oleh sekolah. Nilai- 
nilai moral yang lain adalah kejujuran, keadilan, toleransi, kebijaksanaan, kedisiplinan diri, suka menolong, rasa kasihan, kerja sama, keteguhan hati, dan sekumpulan nilai-nilai demokrasi (Zubaedi, 2011)

Namun demikian, SMP N 4 Singaraja yang merupakan sekolah yang dekat pada lokasi desa permainan Magoak-goakan ini berasal, belum pernah menjadikan permainan Magoakgoakan sebagai sumber bahan ajar pembelajaran IPS. Padahal jika kita kaji lebih dalam kurikulum 2013 mata pelajaran IPS SMP permainan Magoak-goakan dapat dijadikan sumber bahan ajar IPS. Dalam silabus mata pelajaran IPS SMP/kelas VII tema: "Keadaan Alam dan Aktivitas Penduduk Indonesia", sub tema C: "Kehidupan Sosial Masyarakat Indonesia pada masa Praaksara, Hindu Buddha, dan Islam", tercantum KD 1 yaitu memahami perubahan masyarakat Indonesia pada masa Praaksara, masa Hindu Buddha dan masa Islam dalam aspek geografis, ekonomi, budaya, pendidikan dan politik. Dari KD tersebut kita bisa memberikan pengetahuan siswa tentang permainan Magoak-goakan karena permainan Magoak-goakan merupakan kebudayaan di masa Hindu Buddha. Jadi, selain menambah wawasan pengetahuan siswa tentang permainan Magoak-goakan, siswa juga mendapatkan nilai-nilai karakter yang terkandung dalam permainan Magoak-goakan yang dapat membantu siswa hidup bermasyarakat.

Dengan latar belakang di atas, peneliti ingin menggali nilai-nilai karakter pada permainan Magoak-goakan yang nantinya dapat dijadikan sebagai sumber bahan pengayaan pada pembelajaran IPS. Dengan demikian, nilai-nilai karakter yang terkandung dalam permainan Magoak-goakan tersebut akan digali dan diteladani agar mampu membantu proses pendidikan karakter dalam pembelajaran IPS. Maka tesis yang berjudul "Menggali nilai-nilai karakter dalam permainan Magoak-goakan Desa Panji Kecamatan Sukasada sebagai sumber bahan pengayaan pembelajaran IPS SMP Negeri 4 Singaraja." diharapkan dapat membantu proses pendidikan karakter dalam pembelajaran IPS di sekolah-sekolah.

\section{Metode Penelitian}

Penelitian ini menggunakan pendekatan kualitatif. Peneliti menentukan tiga lokasi penelitian, yaitu, Pura Pajenengan, Banjar Dauh Pura Desa Panji, dan SMP Negeri 4 Singaraja.

Penentuan informan dalam penelitian ini menggunakan teknik purposive sampling yaitu penentuan informan kunci, yakni orang-orang yang memang mengetahui dan mengerti tentang masalah yang akan diteliti yakni: (1) Ketua Muda-mudi Desa Panji yakni I Gusti Ketut Adhiguna; (2) Peseta Magoak-goakan yakni Gusti Agus Wirayuda; (3) Kepala Bidang Kesenian yakni I Wayan Sujana; (4) Kepala Desa Desa Panji; dan (5) Guru mata pelajaran IPS SMP N 4 Singaraja. Kemudian dikembangkan lagi dengan teknik Snow Ball yaitu penentuan informasi dengan bantuan informan kunci. Kemudian informan kunci tersebut menunjuk lagi orang-orang yang dianggap mengetahui permasalahan terkait dengan masalah yang diteliti.

Data dikumpulkan dengan menggunakan beberapa teknik pengumpulan data, yakni; (1) Wawancara, penulis melakukan wawancara dengan informan yang mengetahui secara lengkap mengenai permainan Magoak-goakan, untuk memperoleh data-data yang dibutuhkan. Dalam proses wawancara, penulis mengajukan pertanyaan-pertanyaan yang relevan dalam permasalahan yang diangkat. Informan yang telah ditunjuk diwawancarai dengan wawancara mendalam. Agar wawancara bisa berlangsung secara terarah, digunakan pedoman wawancara yang memuat pokok-pokok pikiran yang terkait dengan masalah yang diteliti; (2) Observasi, observasi pebelitian adalah pengamatan sistematis dan terencana untuk memperoleh data yang dikontrol validitas dan reliabilitasnya (Alwasilah, 2002:211-214). Berdasarkan hal tersebut, pertanyaan penelitian tetap merupakan patokan yang menuntun kegiatan observasi, mulai dari identifikasi objek penelitian, penyusunan instrumen observasi, pemilahan data observasi sampai dengan pemaknaan data dan pelaporan hasil observasi. Apapun yang diobservasi, baik berbentuk alat maupun perilaku, didokumentasikan melalui kamera, sehingga apa yang terjadi terdokumentasi dan 
kebenarannya bisa diandalkan. Agar observasi sesuai dengan arah penelitian, maka ditentukan tempat-tempat observasi, yakni; Pura Pajenengan, Lapangan Banjar Dauh Pura Desa Panji dan SMP Negeri 4 Singaraja; (3) Studi Dokumen, studi dokumen merupakan cara pengumpulan data dengan menggunakan peninggalan tertulis. Agar studi dokumen sesuai dengan arah penelitian maka ditentukan dokumen-dokumen yang dijadikan sumber data, yakni: (1) buku Sejarah Buleleng; (2) buku Permainan Rakyat Daerah Bali; (3) Profil Desa Panji; (4) Kurikulum 2013 mata pelajaran IPS; dan (5) Silabus Kurikulum 2013 Mata Pelajaran IPS.

Data-data yang diperoleh tentu tidak semuanya sama, maka dari itu untuk menguji kesahihan data diperlukan sesuatu cross cek atau perbandingan antara data yang diperoleh melalui teknik yang telah dilakukan. Metode triangulasi merupakan metode paling umum yang dipakai dalam penelitian kualitatif. Dalam penelitian ini menggunakan dua teknik triangulasi yaitu triangulasi data dan triangulasi teknik pengumpulan data.

Miles dan Huberman (1992) (dalam Gunawan 2015) mengemukakan tiga tahapan yang harus dikerjakan dalam menganalisis data penelitian kualitatif, yaitu (1) Reduksi Data (data reduction); (2) paparan data (data display); dan (3) penarikan kesimpulan dan verifikasi (conclusion drawing/verifying).

\section{Reduksi Data}

Proses wawancara kepada informan terkadang ke luar dari konteks pedoman wawancara yang telah disusun, sehingga perlu dilakukan reduksi data. Reduksi data meliputi berbagai kegiatan yang bertujuan untuk mempertajam analisis (Miles dan Haberman, 1992 dalam Gunawan, 2015). Reduksi data wawancara dilakukan dengan menghilangkan jawaban - jawaban informan yang ke luar dari konteks pertanyaan pedoman wawancara karena pedoman wawancara sudah disesuaikan dengan rumusan masalah pada penelitian ini.

\section{Pemaparan Data}

Pemaparan data sebagai sekumpulan informasi tersusun, dan memberi kemungkinan adanya penarikan kesimpulan dan pengambilan tindakan (Miles \&Huberman, 1992). Penyajian data digunakan untuk lebih meningkatkan pemahaman kasus dan sebagai acuan mengambil tindakan berdasarkan pemahaman dan analisis sajian data.

\section{Penarikan Kesimpulan}

Penarikan kesimpulan atau verifikasi merupakan hasil penelitian yang menjawab fokus penelitian berdasarkan hasil analisis data. Simpulan yang disajikan dalam bentuk deskriptif objek penelitian dengan berpedoman pada kajian penelitian (Gunawan, 2013)

\section{Hasil dan Pembahasan}

Sejarah Desa Panji dapat ditelusuri dari beberapa dokumen tertulis yaitu salah satunya buku Sejarah Buleleng yang ditulus oleh I Gusti Ngurah Panji tahun 1956. Sejarah Desa Panji berawal dari zaman pemerintahan Dalem Anom Segening berkedudukan di Gelgel. Dalem Sagening banyak memiliki istri salah satunya istri bernama Ni Luh Pasek dari desa Gobleg yang mengabdi di istana Sweca Lingarsa Pura, yang membuat Dalem jatuh cinta. Selanjutnya Ni Luh Pasek dikawini oleh Dalem dengan Pawidiwidanaan.

Setelah Ni Luh Pasek mengandung, kandungannya diserahkan kepada yang tertulis dalam "Babad", mengabdi seorang pepatih di istana Gelgel bernama I Gusti Ngurah Jelantik. Jelantik lama memangku jabatan sebagai pepatih yang disayang oleh Dalem, yang belum mempunyai seorang anak. Itulah sebabnya kandungan bayi Ni Luh Pasek diberi Dalem kepadanya. Tetapi, sentana yang lahir nantinya belum termasuk kadarmaputra karena belum diperas (Diadopsi).

Lebih jauh diceritakan tentang I Gusti Ngurah Jelantik disayang Dalem karena jasajasa leluhurnya terhadap pemerintahan Gelgel, pemberian sentana agar Jelantik tidak 
sampai cepung (tidak ada penerus keturunan). Pada hari yang baik lahirlah seorang bayi laki-laki di karang kepatihan Ngurah Jelantik dan bayi tersebut diberi nama I Gusti Gede Pasekan. Disaat kelahirannya sempat ditimang oleh Kryan Jelantik Bogol sebelum keberangkatannya dalam menjalankan tugas untuk merebut negeri Pasuruhan. Konon beliau bernama Jelantik Bogol, karena pada waktu merebut negeri Nusa Penida sempat menewaskan Dalem Bungkut dengan memogol tanpa senjata. Beliau adalah ayahnya I Gusti Ngurah Jelantik dan I Gusti Gede Pasekan adalah trah Dalem Sri Kresna Kepakisan.

Sebagaimana legenda yang masih dipercaya sampai saat ini, bahwa pada saat kelahirannya Ki Barak menunjukan ciri-ciri yang sangat menonjol yakni pada saat Ki Barak tidur, sang raja melihar cahaya yang memancar dari ubun-ubun (pabaan) Ki Barak. Melihat pertanda tersebut akhirnya sang raja memanggil penasehat istana serta menanyakan tentang apa arti pertanda tersebut. Akhirnya menurut pengamatan spiritualnya, penasehat istana mengatakan bahwa kelak Ki Barak akan menjadi orang yang berpengaruh dan berkuasa di jagat ini. Rupa-rupanya hal ini menimbulkan keresahan dalam hati sang raja tentang keutuhan kerajaan di kemudian hari.

Akhirnya atas saran dari penasihat istana, maka raja Dalem Segening memutuskan untuk meminta kepada Kyayi Manca Warna (Ki Pasek Gobleg) untuk mengajak cucunya ke Den Bukit. Hingga pada akhirnya dia sampai dan menetap di wilayah kekuasaan Ngakan Gendis (yang sekarang bernama Desa Panji).

Sebuah momen yang sangat penting dalam perjalan sejarah Desa Gendis adalah adanya sebuah sayembara besar untuk menolong sebuah kapal laut besar milik seorang pengusaha dari cina bernama Ki Dempu Awang yang karam di Segara Penimbangan. "Barang siapa yang dapat mengembalikan/mendorong kapal tersebut ke tengah laut, maka semua isi kapal tersebut akan dihadiahkan kepadanya." Masyarakat berbondong-bondong untuk mengikuti sayembara tersebut namun tidak ada yang berhasil termasuk Ngakan Dangsang Gendis. Akhirnya Ki Barak pun ikut dalam sayembara tersebut, dengan kemampuan gaib sebilah keris yang dibawanya dia mengacungkan tangannya ke arah kapal tersebut, dan perlahan-lahan kapal tersebut bergerak ketengah laut, seketika itu masyarakat yang menyaksikan bersorak mengelukan-elukan Ki Barak dan Pedagang cina itu pun memberikan semua isi kapalnya yang berupa emas, berlian, kain, beras dan lain sebagainya sehingga membuat Ki barak menjadi kaya-raya.

Melihat prestasi gemilang, dukungan rakyat menjadi semakin besar terhadap Ki Barak, maka Ki Pungakan Gendis kian murka hingga pada akhirnya memutuskan untuk melakukan peperangan dengan Ki Barak. Dalam peperangan itu Ki Pungakan Gendis tewas dan peperangan dimenangkan oleh Ki Barak. Dengan gugurnya raja Pungakan Gendis itu, maka mulai lah era pemerintahan baru di bawah kekuasaan Ki Barak Panji yang kemudian dikenal sebagai I Gusti Ngurah Panji Sakti yang setelah dinobatkan menjadi raja bergelar Anglurah Ki Barak Panji Sakti. Dengan begitu Desa Gendis pun berubah nama menjadi Desa Panji.

Di bawah bendera kerajaan Anglurah Ki Barak Panji Sakti kepentingan rakyat diprioritaskan, serta didukung dengan tata pemerintahan yang baik sehingga Panji Sakti benar-benar mendapat tempat di hati rakyatnya, berwibawa, arif dan bijaksana. Selama pemerintahannya, dia pun secara terus menerus memperluas daerah kekuasaanya hingga pada akhirnya seluruh wilayah Bali Utara (Buleleng) dikuasainya. Belum merasa puas dengan kekusaannya di Bali Utara, Ki Barak terobsesi untuk melakukan perluasan kekuasaan sampai ke Pulau jawa. Beberapa wilayah di pulau jawa yang berhasil di taklukan adalah wilayah Blangbangan.

Selanjutnya hasil Penelitian ini menjelaskan bahwa Permainan Magoak-goakan merupakan sebuah permainan rakyat yang kini hanya masih dapat disaksikan pada satu hari setelah hari raya Nyepi di desa Panji kecamatan Sukasada-Buleleng. Permainan Magoakgoakan merupakan Persiapan I Gusti Ngurah Panji Sakti untuk melakukan penyerangan ke Blambangan. Awal permainan ini dimainkan disaat Panji Sakti menduduki tahta di Puri Sukasada. Di Puri Sukasada dibentuk kesatuan elit dengan sebutan "Taruna Goak" Sebanyak 2000 orang yang memiliki panglima yakni I Gusti Tamblang Sampun dan I Gusti Made Batan. Pasukan Taruna Goak tersebut dimiliki Panji sakti setelah kehadiran Ida 
Peranda Sakti Ngurah Pemada sebagai Bhagawanta puri serta kehadiran Arya Pande Swarna (Pande Beratan) di Sukasada. Pande Beratan telah lebih dahulu memiliki 2000 orang prajurit tersebut yang dipimpin oleh panglima Kyayi Macan Gading yang ditempatkan di Gerembyang (Panji, 1956).Dalam Buku Sejarah Buleleng juga menyebutkan, sebagai seorang raja terpercaya dan bertindak atas dasar keinginan rakyat, maka Ki Barak Panji Sakti memiliki strategi untuk mengajak rakyatnya menyerang kerajaan Blambangan secara demokratis. Beliau selalu menyusun strategi agar penyerangan ke Blambangan itu benarbenar didukung oleh rakyatnya, sehingga raknyatnya melakukan segala kegiatannya secara penuh dan bertanggung jawab.

Pada suatu hari yang baik Ki Panji memanggil patihnya untuk diajak berunding. Raja memerintahkan patihnya supaya mengumpulkan para kesatrianya (para prajuritnya). Di alunalun para ksatria menunggu dengan sabar apa gerangan yang akan dititahkan oleh rajanya yang sangat dicintai. Tidak berapa lama raja datang diiringi oleh perdana menteri, para patih dan pejabat tinggi istana. Raja dengan muka berseri-seri mengumumkan kepada prajurit kepercayaannya bahwa beliau akan menghibur para prajuritnya yang selama ini mendapatkan tugas berperang saja. Raja merasakan berapa beratnya tugas itu. Dihadapan rakyatnya I Gusti Ngurah Panji Sakti mengumumkan:

"Hai prajuritku yang gagah berani, marilah kita bermain sekarang": main Goak-goakan, dan nanti kalau di antara kalian yang bertugas menjadi Burung Gagak dapat menangkap seorang anggota barisan yang paling belakang, maka akan mendapat hadiah besar, tergantung dari permintaan "goak". Kalau para perwiraku yang gagah berani puas mendapat giliran menjadi goak, maka aku juga meminta hak menjadi goak. Dan kalau aku dapat menyelesaikan tugas sebagai goak dengan baik maka akupun minta sesuatu dari prajuritku sekalian". Pengumuman ini dengan senang hati oleh para prajuritnya." (Windhu, 1986). Selanjutnya dalam buku Permainan Rakyat Daerah Bali menyebutkan bahwa pada kesempatan pertama raja menunjuk prajuritnya yang paling rendah pangkatnya untuk menjadi goak yaitu berdiri di depan barisan dan berusaha menangkap peserta yang paling belakang. Usaha ini cukup sulit karena dihalang-halangi oleh peserta yang berbentuk barisan dalam usahanya menangkap yang berada paling belakang. Tatapi karena keras kemauannya maka ia berhasil menangkap peserta paling belakang. Maka betul sabda raja, apapun yang diminta mereka dikabulkan oleh rajanya. Begitu juga seterusnya para prajurit itu bergantian menjadi goak untuk mendapatkan hadiah dari raja. Semua goak yang berhasil menyelesaikan tugasnya mendapatkan hadiah dari raja sesuai dengan yang diinginkannya. Para prajurit sangat puas atas kemurahan hati rajanya. (Windhu, 1986) Akhirnya tibalah giliran I Gusti Ngurah Panji Sakti menjadi goak. Raja berusaha sekuat tenaga menangkap peserta yang terakhir. Sebagai seorang raja yang "Satya Wacana" maka ia pun berusaha memenangkan permainan dengan berusaha menangkap pemain terakhir (Panji, 1956). Dan para prajuritpun bertanya:

"Goak apa budimu?" (Apa yang kau inginkan?)

Para perajurit merasa ketakutan terhadap Ki Barak Panji karena lama berdiam diri dan tidak memberikan jawaban. Dan setelah menunggu beberapa saat jawaban dari Raja, Akhirnya I Gusti Ngurah Panji Sakti bersabda:

"Manira apti elawan bhumi ngaran ing bhumi Blambangan didinya kawawa de manira" artinya: saya ingin melawan negeri Blambangan agar menjadi daerah kekuasaanku (Panji,1956)

Sabda beliau tersebut mengandung maksud untuk mengajak para prajurit Taruna Goak untuk melakukan penyerangan terhadap kerajaan Blambangan. Maka para prajurit bersorak-sorai dengan bangga, karena sebagai seorang prajurit pada mulanya camas apa nanti yang akan diminta oleh rajanya. Tetapi permintaan dari raja untuk menyerang Blambangan, sebagai seorang prajurit bukan hal yang luar biasa. Maka prajurit menyambut dengan gembira dan pada saat itu diputuskan bahwa raja Panji Sakti akan menyerang Blambangan. Nilai-nilai yang terkandung dalam permainan Magoak-goakan yakni, (1) Nilai disiplin Sikap disiplin diperlihatkan oleh masyarakat Desa Panji ketika melaksanakan permainan Magoak-goakan. Masyarakat yang mengikuti permainan Magoak-goakan wajib 
untuk mengikuti aturan-aturan dalam permainan Magoak-goakan; (2) Nilai Kerjasama/gotong-royong, permainan Magoak-goakan sangat membutuhkan kerjasama tim. Karena yang menjadi ular akan bersama-sama menghadang goak yang akan memangsa ekor ular. Sangat sulit untuk berlarian di lapangan yang berlumpur maka dari itu diperlukan kekompakan dari para peserta permainan Magoak-goakan; (3) Nilai religius juga terkandung dalam permainan Magoak-goakan ini karena sebelum permainan Magoak-goakan, para peserta wajib untuk melakukan persembahyangan bersama guna mengucap syukur sekaligus memohon ijin untuk memainkan permainan Magoak-goakan tersebut. (4) Nilai Toleransi, sikap toleransi ini tampak pada saat permainan Magoak-goakan dimulai seluruh masyarakat Desa Panji ikut berpartisipasi di dalamnya. Masyarakat tidak membeda-bedakan masyarakat kaya, miskin, pejabat, petani, Pra-Gusti, Jaba atau masyarakat lainnya. Seluruh masyarakat berkumpul bersama-sama, bermain bersama dan saling menghargai sesama masyarakat Desa Panji dan masyarakat lainnya. (5) Nilai Kerja Keras, sikap kerja keras dalam permainan Magoak-goakan ini sangat jelas terlihat saat permainan Magoak-goakan ini dilaksanakan. Seorang yang bertugas menjadi goak akan bekerja keras untuk mendapatkan ekor ular. Begitu juga yang menjadi kepala ular dan ekor ular akan berusaha keras menghindari tangkapan goak yang ingin menyambar ekor ular; (6) Nilai Komunikatif, masyarakat yang ikut permainan Magoak-goakan terlihat sangat bersahabat satu sama lain menikmati serunya permainan Magoak-goakan. Suasana yang sangat harmonis terlihat saat permainan dimulai sembari melempar senyum suka cita dalam melaksanakan permainan Magoak-goakan.

Pengintegrasian permainan Magoak-goakan ke dalam pembelajaran IPS diperlukan strategi-strategi dalam penyusunan RPP Kurikulum 2013 mata pelajaran IPS. Adapun strategi pengintegrasian nilai-nilai karakter dalam permainan Magoak-goakan kedalam pembelajaran IPS adalah dengan (1) meninjau silabus, (2) menentukan KD yang relevan, (3) memilih topik pada buku ajar yang relevan, (4) menyusun RPP yang mencerminkan pengaplikasian permainan Magoak-goakan sebagai sumber belajar.

\section{Simpulan dan Saran}

Dari rangkuman tersebut dapat ditarik kesimpulan bahwa permainan Magoak-goakan merupakan permainan tradisional yang memiliki nilai sejarah. Permainan ini merupakan siasat Ki Barak Panji Sakti untuk mempersatukan rakyat dalam usahanya berperang melawan kerajaan Blambangan. Nilai-nilai yang terkandung dalam permainan Magoakgoakan yakni: nilai disiplin, nilai kerjasama, nilai religius, nilai toleransi, nilai kerja keras, dan nilai komunikatif. Pengintegrasian permainan Magoak-goakan ke dalam pembelajaran IPS diperlukan strategi-strategi dalam penyusunan RPP Kurikulum 2013 mata pelajaran IPS. Adapun strategi pengintegrasian nilai-nilai karakter dalam permainan Magoak-goakan kedalam pembelajaran IPS adalah dengan (1) meninjau silabus, (2) menentukan KD yang relevan, (3) memilih topik pada buku ajar yang relevan, (4) menyusun RPP yang mencerminkan pengaplikasian permainan Magoak-goakan sebagai sumber belajar. Berdasarkan temuan di lapangan maka ada beberapa saran yang diberikan, yaitu:

\section{Bagi Guru IPS}

Mata pelajaran IPS tidak dapat dilepaskan dari masyarakat, oleh sebab itu disarankan bagi guru IPS pada jenjang SMP dalam proses pembelajaran untuk mencari sumber materi yang ada di dekat lingkungan siswa. Saat ini guru yang kreatif dan inovatif, guru yang peka dengan lingkungan sekitar dan guru yang dapat mengaplikasikan model pembelajaran inovatiflah yang dibutuhkan dalam pembelajaran IPS

2. Bagi Masyarakat Setempat

Bagi masyarakat desa Panji, kelestarian budaya yang ada di desa Panji wajib untuk dilestarikan. Selain merupakan budaya dari para pendahulu didalam sebuah budaya terdapat nilai-nilai karakter manusia yang dapat berguna dalam kehidupan bermasyarakat

3. Bagi Sekolah 
Bagi sekolah-sekolah hendaknya tidak mengesampingkan keberadaan lingkungan sebagai sumber materi terutama mata pelajaran IPS. Sehingga, sumber yang ada di lingkungan sekitar dapat bermanfaat untuk kepentingan pendidikan.

4. Bagi Pemerintah

Pemerintah daerah hendaknya lebih memperhatikan kebudayaan-kebudayaan yang ada di tengah-tengah masyarakat khususnya permainan tradisional Magoak-goakan yang merupakan warisan dari Raja Buleleng, Ki Barak Panji Sakti. Pemerintah daerah dapat merancang program yang mengakomodasi kebudayaan-kebudayaan yang ada di tengahtengah masyarakat

5. Bagi Siswa

Meskipun mata pelajaran IPS dianggap oleh sebagian siswa mata pelajaran yang membosankan, tetapi keberadaan mata pelajaran IPS ini sangat membantu siswa dalam menjalani kehidupan sebagai warga negara yang baik. Jadi siswa-siswi khususnya diharapkan untuk mencintai dan mengamalkan ilmu-ilmu pada mata pelajaran IPS khususnya nilai-nilai karakter yang terkandung dalam permainan Magoak-goakan.

\section{Daftar Rujukan}

Alwasilah, A. dan Chaedar. 2002. Pokoknya Kualitatif: Dasar-dasar Merancang dan Melakukan Penelitian Kualitatif. Jakarta. Pustaka Jaya

Budi, Udik Wibowo, 2010. Pendidikan dari Dalam: Strategi Alternatif Pengembangan Karakter. Diambil dari Jurnal Dinamika Pendidikan No. 01/Th.XVI/Mei 2010

Danandjaja, James, 2002. Foklor Indonesia: IImu Gosip, dongeng, dan lain lain. Jakarta Pustaka Utama Grafiti

Departemen Pendidikan Nasional, 2010. Pendidikan Karakter Teori \& Aplikasi. Jakarta: Direktoral Jendral Manajemen Pendidikan dan Menengah Kementrian Pendidikan Nasional

Emzir. 2009. Metodologi Penelitian Pendidikan, Kuantitatif dan Kualitatif. Jakarta: Raja Grafindo Persada

Gunawan, Imam. 2015. Metode Penelitian Kualitatif: Teori dan Praktik. Jakarta: Bumi Aksara

Hidayat, Soleh. 2013. Pengembangan Kurikulum Baru. Bandung: PT Remaja Rosdakarya Bandung

Kemendikbud .2016. Permendikbud Nomor 22 Tahun 2016 Tentang Standar Proses Pendidikan Dan Menengah. Jakarta: Kemendikbud.

Khan, Yahya, 2010. Pendidikan Karakter Berbasis Potensi Diri Mendongkrak Kualitas Pendidikan. Yogyakarta: Pelangi Publishing.

Koentjaraningrat, 1990. Pengantar IImu Antropologi, Jakarta: Djambata

Kumbara, A.A. Ngurah Anom, 2012. Wacana Antropologi: Membaca Ulang Teks Kebudayaan Menuju Tranformasi Diri dalam Multikulturalisme. Denpasar: Pustaka Larasan

Kunandar, 2013. Penilaian Autentik (Penilaian Hasil Belajar Peserta Didik Berdasarkan Kurikulum 2013). Jakarta: Raja Grafindo Persada 
Kurniasih, Imas. 2014. Implementasi Kurikulum 2013 Konsep dan Penerapan. Surabaya: Kata Pena

Lagulung, Hasan, 2000. Asas-asas Pendidikan. Jakarta: Al-Husnah

Muchtar, Suwarma. 2001. Pengembangan Kemampuan Berpikir dan Nilai dalam Pendidikan IPS. Bandung: Gelar Pustaka Mandiri

Muhtadi, Ali, 2010. Strategi Implementasi Pendidikan Budi Pekerti yang Efektif di Sekolah. Diambil dari Jurnal Dinamika Pendidikan No. 01/Th.XVI/september 2014

Muslich, Masnur. 2013. Pendidikan Karakter menjawab tantangan krisis Multidimensional. Jakarta: Bumi Aksara.

Nur, Haerani. 2013. Membangun Karakter Anak Melalui Permainan Anak Tradisional. TH. III, No. 2. Hal. 10 https://journal.uny.ac.id . Diakses pada 2 September 2017

Panji, I Gusti Ngurah, 1956. Sejarah Buleleng. Pemerintah Kabupaten Buleleng: UPTD Gedong Kirtya.

Purwadi. 2009. Folklor Jawa. Yogyakarta: Pura Pustaka

Qoyyimah, Nurul. 2016. Penerapan permainan tradisional untuk meningkatkan perkembangan sosial emosional anak kelompok di RA. Baitul Muta'allim. Volume 4. No. 2. Hal. 11 https://ejournal.undiksha.ac.id. Diakses pada 2 September 2017.

Sapriya, 2009. Pendidikan IPS Konsep dan Pembelajaran. Bandung: PT. Rosdakarya

Sihabuddin, Rabad, 2006. Indahnya Pelangi Dalam Kesadaran Multikultur Masyarakat Indonesia. Direktorat Pendidikan Nasional Direktorat Jendral Pendidikan Tinggi Direktorat Ketenagaan.

Soemantri, Muhammad Numan, 2001. Menggagas Pembaharuan Pendidikan IPS. Bandung: Program Pascasarjana-UPI dan Fakultas Pendidikan IImu Pengetahuan Sosial- UPI

Sudrajat. 2015. Muatan nilai-nilai karakter melalui permainan tradisional di PAUD among siwi, panggungharjo, sewon, bantul. JIPSINDO No 1 Volume 2. Hal. 1 https://journal.uny.ac.id . Diakses pada 2 September 2017

Sugiyono, 2009. Metode Penelitian Kuantitatif, Kualitatif dan R\&D. Bandung: Alfabeta

Supada, I Nyoman Buda. 2012. Tradisi Magoak-goakan di Desa Pakraman Panji, Kecamatan Sukasada, Kabupaten Buleleng (Analisis Bentuk, Fungsi, dan Makna). https://download.portalgaruda.org/article. Diakses pada 2 September 2017

Supardi, 2011. Dasar-dasar IImu Sosial. Yogyakarta: Penerbit Ombak

Sutopo, 2006. Metodelogi Penelitian Kualitatif. Surakarta: UNS

Suyeni, Putu Winda, dkk. 2016. Penerapan Metode Demonstrasi Melalui Permainan Tradisional Magoak-goakan Untuk Meningkatkan Kemampuan Kerjasama. Volume 4. No. 2. Hal. 10 https://ejournal.undiksha.ac.id . Diakses pada 2 September 2017

Trianto, 2010. Model Pembelajaran Terpadu. Jakarta: PT. Bumi Aksara 
Windhu, Ida Bagus Oka. 1986. Permainan Rakyat Daerah Bali. Departemen Pendidikan dan Kebudayaan Proyek Inventarisasi dan Dokumentasi Kebudayaan Daerah

Yunus, 1981. Permainan Rakyat Daerah Istimewa Yogyakarta. Yogyakarta: Departemen Pendidikan dan Kebudayaan Daerah.

Zubaedi, 2011. Desain Pendidikan Karakter: Konsepsi dan Aplikasinya dalam Lembaga Pendidikan. Jakarta: Kencana Prenada Media Group.

Zuriah, Nurul. 2007. Pendidikan Moral dan Budi Pekerti dalam Perspektif Perubahan. Jakarta: Bumi Aksara

Suyadi. 2013. Strategi Pembelajaran Pendidikan Karakter. Bandung: PT. Remaja Rosdakarya. 